\title{
Taiwan's Paradoxical Perceptions of the Chinese Military
}

More Capable but Less Threatening?

Arthur S. Ding and Paul A. Huang

\section{(Q) OpenEdition \\ Journals}

Electronic version

URL: http://journals.openedition.org/chinaperspectives/5742

DOI: $10.4000 /$ chinaperspectives.5742

ISSN: 1996-4617

Publisher

Centre d'étude français sur la Chine contemporaine

Printed version

Date of publication: 30 December 2011

Number of pages: 43-51

ISSN: 2070-3449

Electronic reference

Arthur S. Ding and Paul A. Huang, «Taiwan's Paradoxical Perceptions of the Chinese Military », China Perspectives [Online], 2011/4 | 2011, Online since 30 December 2014, connection on 28 October 2019. URL : http://journals.openedition.org/chinaperspectives/5742 ; DOI : 10.4000/chinaperspectives.5742

(c) All rights reserved 


\title{
Taiwan's Paradoxical Perceptions
}

\section{of the Chinese Military}

\author{
More Capable but Less Threatening?
}

\author{
ARTHUR S. DING AND PAUL A. HUANG*
}

\begin{abstract}
Against the backdrop of China's thriving economic development since the 1980s, the rapid modernisation of the People's Liberation Army has always been Taiwan's top national security concern. This article argues that, despite the military threat posed by the Chinese military to Taiwan, China's changing policy toward the island, combined with the US determination to remain the leading power in the AsiaPacific region, and the realisation of the complexity of Taiwan politics by the Chinese leadership, have led Taiwanese analysts to perceive the likelihood of conflict as decreasing. This constitutes a major perceptual contrast between long-term threat and short-term stability in crossStrait relations.
\end{abstract}

\section{KEYWORDS: Chinese Military, Perception of China Military, Taiwan-China Relations, Taiwan's Military Modernisation, Hard ROC}

S ince the 1950s, shortly after the Kuomintang (KMT, or Nationalist Party) government moved to Taiwan after having suffered defeat in mainland China by the Chinese Communist Party (CCP), Taiwan has been under the shadow of military threat from the Chinese People's Liberation Army (PLA). In the 1980s, as mainland China began to open and reform, prioritising economic development over class warfare and military strengthening, Taiwan observers came to perceive a decline in the level of threat posed by the mainland. By the post-Cold War era, however, as Taiwan democratised, perceptions of threat returned and were reinforced by events such as the 1995/1996 Taiwan Strait crisis, in which China test-fired ballistic missiles near Taiwan's main ports and launched live-fire military exercises in the East China Sea. China's annual double-digit military budget growth in the past two decades and successive revelations about newlydeveloped high-end weapon systems also contributed to resurgent anxieties about Chinese intentions.

Surprisingly, however, in the mid-2000s, and in spite China's widelyrecognised comprehensive military modernisation, the PLA's continuous deployment of ballistic missiles opposite Taiwan, and Beijing's refusal to rule out the possibility of using military force against Taiwan, a new perception began to take root among Taiwanese observers that the likelihood of cross-Strait military conflict was decreasing. This article argues that the PRC's changing policy toward Taiwan combined with the clear US determination to remain the leading power in the Asia-Pacific has led Taiwanese analysts to perceive the likelihood of conflict in the near-term as decreasing. This constitutes a major perceptual contrast between long-term threat and short-term stability.

This paper is divided into four sections. The first section deals with Taiwan's threat perceptions of China and the impact these perceptions have had on the island's defence posture. The second section focuses on the shift in China's military approach towards Taiwan. The third section analyzes Taiwan's evolving defence/military strategy toward the decreasing likelihood of cross-Strait conflict. The final section analyzes Taiwan's defence modernisation in the face of China's continuing military threat and the prospect of cross-Strait confidence building.

\section{Taiwan's evolving perceptions of the China threat}

Taiwan's long-held perception of an existential military threat from China began to abate in the late 1980s, especially after 1987, when the Taiwan government, pressured by the opposition movement for humanitarian articulation, approved home visits for retired soldiers, allowing veterans to return to their birthplaces in China for the first time in nearly 40 years. This change of policy on home visits, along with China changing its policy toward Taiwan by advocating "peaceful re-unification under one-country, two-systems," ushered in a new stage for Taiwan-China exchanges.

Despite the fact that Taiwan and China started to deal with each other on functional issues from this point onwards and trade and economic ties became closer, the two sides' fundamental political differences remained unchanged at this stage. ${ }^{(1)}$ Taiwan was actively seeking to improve its international status on the grounds that its achievements in economic, political, and social development should be recognised by the international community and rewarded with a more normal international status. Further, Taiwan under the name of Republic of China (ROC) has long been a sovereign state, and should be recognised as such with an official representative in all international organisations. Beijing regarded Taiwan's endeav-

Arthur S. Ding is Research Fellow and Acting Director, Institute of International Relations (IIR) at National Chengchi University (NCCU), Taipei, Taiwan; Paul A. Huang is Postdoctoral Research Fellow, IIR, NCCU.

1. The core difference focuses on sovereignty and security. For a comprehensive analysis on the political difference between Taiwan and China, see Richard Bush, Untying the Knot - Making Peace in the Taiwan Strait, Washington, Brookings Institution, 2005, Chapters 3-5, pp. 27-141. 
ours to achieve international recognition, symbolised most notably by former President Lee Teng-hui's (李登輝) visit to his alma mater Cornell University in 1995 and all-out effort to return to the international community, as synonymous with the pursuit of "Taiwan independence." (2)

As such, the incipient cross-Strait cooperation on functional issues symbolised by the Koo-Wang talks in 1993 in Singapore soon broke down, and the result of this breakdown was the 1995-96 Taiwan Strait crisis. ${ }^{(3)}$ In the wake of Lee's visit to Cornell, China test fired short-range ballistic missiles into the sea about 90 miles north of Taipei. The PLA Navy also launched live fire exercises in the East China Sea. Amphibious landing exercises were carried out on an island close to Taiwan. China's state-controlled media swung into action, roundly condemning Taiwan's quest for "independence" and emphatically pointing out that the PLA had the ability to crush Taiwan's attempt if necessary. Although the crisis ended without any direct military clash, it shocked Taiwan in many ways.

The foremost effect was to drive home Beijing's willingness to contemplate the use of force against Taiwan, dispelling the un-realistic hopes that had arisen in Taiwan since 1987 that peace in the Taiwan Strait was inevitable, and that there was no longer any realistic prospect of armed conflict. China's show of determination reminded Taiwanese observers of Beijing's willingness to use force to attain its political goals.

A related view around that time was that China had no capability to invade Taiwan. There was a widespread view among Taiwanese analysts prior to the 1995-96 crisis that the Chinese military could best be described as having "short arms and slow legs." (4) This line of analysis implied that the PLA lacked the capability to invade Taiwan, let alone execute the mission of the "limited war under high-technology conditions" doctrine.

In the wake of the crisis, Taiwanese analysts' perceptions of the PLA began to shift, with more and more observers believing that China would use force against Taiwan if it felt its interests threatened, regardless of whether or not the PLA possessed advanced weapons systems in its inventory.

The crisis also affected military planning in Taiwan. While the Chinese military was not able to cross the Taiwan Strait at this time due to insufficient amphibious lift capability, and the PLA Air Force was not yet able to threaten serious damage to Taiwan, China's growing ballistic missile forces were providing Beijing with a new tool enabling it to strike Taiwan in ways that the ROC armed forces could not effectively defend against.

Ballistic missiles represented one of the few pockets of excellence amid China's overall quite obsolete weapons systems inventory, and they were probably the most lethal. ${ }^{(5)}$ With its expanding arsenal of conventional surface-to-surface ballistic missiles, China could target and hold at risk Taiwan's major political and military assets. While questions about the accuracy of its missile force persisted, if China launched an all-out assault on Taiwan's command and control centres, the possibility existed that these could be paralysed, if not totally knocked out. Were that to occur, Taiwan could lose retaliatory capability and might struggle to mount an effective defence against invasion.

On the basis of the 1995-96 crisis, most Taiwan military analysts concluded that a ballistic missile strike would be the opening act of any future cross-Strait conflict. Before it committed any other weapons or platforms to the field of battle, Beijing was likely to try to soften up Taiwan's defences using its stand-off strike capabilities, which could easily penetrate Taiwan's air defence system. Furthermore, using missiles would be highly cost effective for China, potentially saving thousands of Chinese soldiers' lives by weakening Taiwan's resistance in the event of an actual conflict. At the same time, Beijing could exhaust Taiwan's limited defence procurement resources if it could induce Taiwan to spend heavily on developing and deploying expensive anti-missile systems.

Taiwan's perception of a threat from China intensified as more information about the PLA's ambitious "strategic modernisation" program became available. ${ }^{(6)}$ Research has shown that the Chinese military was not content with developing ballistic missiles alone, but also invested significantly in acquiring comprehensive information warfare capabilities, in modernising the PLA's special forces, in improving China's electronic warfare and electronic counter-measures abilities, and in significantly upgrading the PLA's command, control, communications, computers, intelligence, surveillance, and reconnaissance (C4ISR) capabilities. In other words, Taiwan faces tremendous challenges from the modernisation investments made by its chief military threat. As such, Taiwan has to confront a multi-vector military challenge, even as doing so could cost it tremendous resources in terms of defence expenditure. ${ }^{(7)}$

China has also reportedly explored the possibility of carrying out a decapitation strike against Taiwan's political and military leadership. The risk, as seen by some analysts, is that the PLA may at some point be able to shorten the sensor-to-shooter target acquisition and weapons-release chain, allowing it to execute the kind of long-range precision strike necessary to execute a decapitation attack against Taiwan. ${ }^{(8)}$

An additional concern noted by US analysts of the PLA stems from the Chinese military's development of anti-access/area-denial (A2/AD) capabilities. These A2/AD capabilities aim at denying US forces the option of forward-basing and/or sea access so as to prevent the US from intervening in the Taiwan Strait if military conflict erupted between Taiwan and China. ${ }^{(9)}$

2. Ibid.

3. It should be emphasised that China's suspicion of former ROC President Lee Teng-hui's behaviour started around 1993, and military exercises were launched to warn Taiwan away from pursuit of independence. See Michael Swaine, "Chinese Decision Making Regarding Taiwan, 1979-2000," in David Lampton (ed.), The Making of Chinese Foreign and Security Policy in the Era of Reform, 1978-2000, Stanford, Stanford University Press, 2001, pp. 289-336. For an analysis on the 1995-96 Taiwan Strait crisis, see Zhao Suisheng, Across the Taiwan Strait: Mainland China, Taiwan, and the 1995-1996 Crisis, London, Routledge, 1999.

4. Russell D. Howard, "The Chinese People's Liberation Army: 'Short Arms and Slow Legs'," INSS Occasional Paper 28, September 1999, Colorado, USAF Institute for National Security Studies, USAF Academy, www.usafa.edu/df/inss/OCP/ocp28.pdf (consulted on 12 December 2012). According to Howard, this term was first used by a PLA general.

5. Mark Stokes, China's Evolving Conventional Strategic Strike Capability, Project 2049 Institute, Arlington, 14 September 2009. pp. 6-13, http://project2049.net/documents/chinese_anti_ship_ballistic_ missile_asbm.pdf (consulted on 13 December 2011).

6. The term is borrowed from a ground-breaking analysis by Mark Stokes. See Mark A. Stokes, China's Strategic Modernization: Implications for the US; Carlisle, PA: US Army War College Strategic Studies Institute, 1999, www.strategicstudiesinstitute.army.mil/pubs/display.cfm?publD=74 (consulted on 13 December 2011).

7. It should be pointed that as the Chinese military develops information warfare/information operation related capability, Taiwan is also shifting its conception of Chinese military action against Taiwan from missile first to information/cyber attack first. With this conceived shift, development of information/electronics operation was prioritised. See ROC National Defense Report 2004, Taipei Ministry of National Defense, 2004, pp. 80-82.

8. Robert Pape, "Why a Chinese Preemptive Strike against Taiwan would Fail," Taiwan Defense Affairs, vol. 3, no. 2, Winter 2002/03, www.taiwanus.net/Taiwan_Future/national_defence/2002/03_02/ 03_02_10_01.htm (consulted on 13 December 2011); Liu Kuang-hua, "How the Coalition Force Defeats the Iraqi," Taiwan Defense Affairs, vol. 3, no. 3, Spring 2003, pp. 98-122.

9. This term was first introduced in official US Department of Defense lexicon in the 2001 Quadrennial Defense Review to characterise attempts to prevent the US military from intervening should China elect to attack Taiwan. For a comprehensive analysis of the PLA Navy's role in A2/AD, see Michael McDevitt, "China's Naval Modernization: Cause for Storm Warning?", read at the US National Defense University-sponsored 2010 Pacific Symposium, Washington DC, 16 June 2010, www.ndu.edu/inss/docuploaded/PLAN_McDevitt_Remarks.pdf (consulted on 13 December 2011). It seems that there are different views over how the PLA will execute the A2/AD mission, and one school argues that the PLA will place priority on denying the US force while leaving Taiwan alone with a conviction that if US force can be denied, Taiwan will surrender immediately. 
China's A2/AD capability is widely assessed to centre around the acquisition of intermediate-range anti-ship ballistic missiles (ASBMs) able to manoeuvre after re-entering the atmosphere so as to hit a moving US aircraft carrier. ${ }^{(10)}$

Previously, many analysts discounted the possibility of employing ASBMs against US aircraft carrier battle groups due to the technical complexities of such a task. China's purported ASBM, the Dongfeng (DF)-21 series missile, has a reported range of about 2,500 $\mathrm{km}$, and when re-entering the atmosphere, its speed would be more than Mach 7.0. (11) At such a high speed, many defence analysts assessed it to be virtually impossible to manoeuvre the missile's direction effectively enough to hit a US carrier.

However, it seems that China's researchers refused to give up the quest to produce an ASBM and may in fact be on the verge of success. Several models have been developed, from the DF-21A to the DF-21D, and senior US military officers appear to believe that these missiles could in fact pose a threat to US carriers. ${ }^{(12)}$ At a minimum, the PLA's ASBM program has created a psychological effect on US forces and on China's neighbours, some of whom may suspect that if the US can be deterred from entering the Taiwan Strait area, Washington's overall determination to remain the leader of the region itself may also be called into question.

Additionally, China's refurbishment of the ex-Varyag aircraft carrier, purchased from the Ukraine, has demonstrated its determination to develop a blue-water navy. (13) While there is little doubt that it will take many years for China to build and operate an aircraft carrier strike group, news reports of the refurbishment and possible testing of the carrier have nevertheless generated speculation about the impact on the regional geostrategic landscape. Additionally, the carrier's launching has placed psychological pressure on Taiwan, forcing ROC military analysts to ponder how Taiwan should react if China's aircraft carrier group should launch military action in the waters east of Taiwan.

China drew a number of lessons from the 1995-96 Taiwan Strait crisis, the most important of which was that the US would intervene in one way or another if a military conflict erupted in the Taiwan Strait. (14) In light of this, the PLA needed to prioritise investing heavily in the development of anti-ship missile capabilities, along with other asymmetric weapons systems so that the US would be deterred from intervening, or at a minimum that the cost of any possible US intervention would be substantially heightened. By December 2009, the PLA had deployed between 1,050 and 1,150 CSS-6/7 short-range ballistic missiles to units opposite Taiwan. ${ }^{(15)}$ China's preparations for deterring or defeating possible US intervention in the Taiwan Strait have intensified Taiwan's perceptions of a rising military threat from China.

Given Beijing's claim that Taiwan is a part of China, using military force against a Taiwan that Beijing views as falling internally within its own borders has always been an option. Although the military threat to Taiwan has increased dramatically over the years as China has deployed around 1,150 ballistic missiles along the Taiwan Strait, the PRC has gradually changed its policy strategy towards Taiwan in recent years. ${ }^{(16)}$ The evolution of Beijing's policy towards Taiwan has been described by one ROC analyst as "more carrot than stick." (17)

\section{The shift in China's military approach towards Taiwan}

As China's policy towards Taiwan has changed from a tougher approach during the Jiang Zemin era to a more moderate approach under $\mathrm{Hu}$ jintao today, the role of military force has been correspondingly downgraded in terms of prominence, although by no means abandoned. This change is largely tactical, since Beijing's ultimate goal of eventual re-unification under the one China principle remains unchanged.

Reasons for the change in policy approach have never been formally disclosed by Beijing. Nevertheless, reasonable speculation is possible. On the one hand, military exercises in the 1995-96 Taiwan Strait crisis and the hawkish remarks made by Premier Zhu Rongji immediately before Taiwan's 2000 Presidential election all backfired, and Taiwan people were alienated despite the fact that a trend for "Taiwan independence" did not come about. The backfiring of a forceful policy by Beijing could be seen as early as in the landslide victory of Lee Teng-hui in Taiwan's 1996 Presidential election.

On the other hand, China's diplomatic environment also suffered from its forceful approach to Taiwan in the late 1990s. The "China threat" theory emerged as a result of the hawkish behaviour exhibited by the PLA, and this served to isolate China by encouraging the US to develop closer security ties with Taiwan and to strengthen the US-Japan alliance. It was also detrimental to China's goal of building better relations with its neighbouring countries, particularly those in Southeast Asia.

As such, the hardline policy had largely failed to achieve its aims, and had to be changed. This change coincided with the transition from jiang Zemin to $\mathrm{Hu}$ Jintao. ${ }^{(18)}$ As the leading figure of the fourth generation of CCP leaders, Hu took control over the party, state, and military step-by-step from Jiang between the years 2002 and 2005. During this period, Taiwan-China relations also embarked on a new trajectory with the revival of CCP-KMT cooperation marked by the visit of then-KMT chairman Lien Chan to China in 2005. ${ }^{(19)}$ The completion of Beijing's power transition and Lien's visit to

10. Norman Friedman, "China Working on Anti-Ship Ballistic Missiles," Naval Institute Proceedings, July 2006, pp. 90-91.

11. Mark Stokes, China's Evolving Conventional Strategic Strike Capability, pp. 1-10.

12. "China has carrier-killer missile, US admiral says," Washington Times, 27 December 2010 www.washingtontimes.com/news/2010/dec/27/china-deploying-carrier-sinking-ballistic-missile, (consulted on 13 December 2011).

13. Kathrin Hille and Mure Dickie, "China Reveals Aircraft Carrier Plans," Financial Times, 17 December 2010, www.ft.com/intl/cms/s/0/fa7f5e6a-09cc-11e0-8b29-00144feabdc0.html\#axzz1CjN5KgW0 (consulted on 13 December 2011).

14. Arthur S. Ding, "The Lessons of the 1995-1996 Military Taiwan Strait Crisis: Developing a New Strategy toward the US and Taiwan," in Laurie Burkitt, Andrew Scobell, and Larry Wortzel (eds.), The Lessons of History: The Chinese People's Liberation Army at 75, Carlisle (PA), US Army War College Strategic Studies Institute, 2003, pp. 379-402, www.strategicstudiesinstitute.army.mil/pubs/display.cfm?publD=52 (consulted on 13 December 2011).

15. Office of the Secretary of Defense, Annual Report to Congress - Military and Security Developments Involving the People's Republic of China 2010, Washington, Office of the Secretary of Defense, 2010, pp. 1-2.

16. The Minister of the Taiwan Affairs Office of the State Council, Wang Yi, once stated that China's deployment of numerous ballistic missiles along the Strait is mainly for its security needs and is not aimed at Taiwan people. However, his statement cannot reduce Taiwan's perceptions of the Chinese military, because Taiwan's China-threat perception and military build-up are tied to China's missile deployment, not to the number of its missiles. For Wang Yi's talk, see Chen Fang-ming, "Zhongguo zai jiaolü shenme?" (What is China worried about?), China Times, 4 August 2011, http://mag.chinatimes.com/print.aspx?artid=9155 (consulted on 13 December 2011).

17. Lin Chong-pin, "More carrot than stick: Beijing's emerging Taiwan policy," China Security, vol. 4, no. 1, Winter 2008, p. 4.

18. You Zhiwei and Chen Zhengyi, "Zhonggong dui tai zhengce zhi lixing yu zuzhi guocheng fenxi: yi 20022010 nian de zhengce bianhua weili" (China's Taiwan policy in 2002-2010: Rational and organisational analyses), Zhongguo dalu yanjiu (Mainland China Studies), vol. 54, no. 4, December 2011.

19. The two parties have decided to jointly promote developments in five aspects, including (1) promoting the earlier restoration of cross-Strait talks, (2) the formal end of the state of hostility across the Strait, (3) all-round economic cooperation and trade across the Strait, (4) discussions about Taiwan's participation in international activities, and (5) the establishment of a platform for regular exchanges between the two parties. See "Hu-Lien meeting raises hope for cross-Strait relations," China Daily, 30 April 2005, www.chinadaily.com.cn/english/doc/2005-04/30/content_439001_2.htm (consulted on 13 December 2011). 
China represented a milestone in terms of China's military posture in its Taiwan policy, allowing China to move Taiwan policy from a hard to a soft approach, while still refusing to abandon the option of using military means against Taiwan in order to block Taiwan independence.

For instance, Hu's keynote speech before the $17^{\text {th }}$ Party Congress in 2007 greatly soft-pedalled the Taiwan issue, and did not mention the mantra of opposing Taiwan's independence and two Chinas. ${ }^{(20)}$ Again, in his Political Report at the $17^{\text {th }}$ Party Congress, Hu offered Taiwan the opportunity to negotiate a peace accord. (21) The changes in China's approach toward Taiwan under Hu laid the foundation for the later dramatic improved atmosphere in cross-Strait relations. There are several significant dimensions worth noting in the shift in China's Taiwan policy since the Jiang-Hu transition of leadership.

Militarily, Beijing reduced its public emphasis on the potential use of force against Taiwan. Military tension flared up three times during the jiang era in 1995, 1996, and 1999. By contrast, no such incidents have happened under $\mathrm{Hu}$ Jintao. Instead, Beijing has stressed non-military approaches to deal with Taiwan, and in a sense, Beijing has adjusted its means to influence Taiwan softly and comprehensively. For instance, the much-touted Dongshan Island military exercises previously held annually near the Taiwan Strait ceased in 2005, after having been scaled down in 2004. In response, Taipei announced the cancellation of the Han Kuang drill scheduled for 9 September 2004. (22) Further, PLA amphibious and airborne exercises perceived as simulated attacks on Taiwan have been held elsewhere, a step aimed at reducing the provocative nature of the drills.

This does not mean Beijing has given up the military approach, but rather that it prefers to stress softer approaches, even while still regarding the use of force as a last option. In 2007, Hu pointed out that the main mission of the PLA is to win a war with Taiwan, but also noted that attacking the island would cause several negative results, including damaging economic development along China's southeast coast, impairing Beijing's foreign relations, harming foreign investment in China, causing causalities, and pushing back the progress of China's national modernisation. (23)

Although Hu proclaimed the tough-sounding "Anti-Secession Law" (ASL) (24) in 2005 to guard against the prospect of a declaration of Taiwan independence, and although the law was widely perceived as a step toward preparing the legal grounds for war against Taiwan, the law was actually meant more as a step to unshackle the hands of China's Taiwan affairs experts to promote cross-Strait engagement free from hawkish internal opposition than as an attempt to intimidate Taiwan, even if Taiwan was further antagonised and alienated as a result. In other words, the ratification of the ASL served two goals: it sought to hold off any potential criticism of Hu's new Taiwan policy on the one hand, while at the same time attempting to buy time for a new approach aimed at winning the hearts and minds of Taiwanese people for the ultimate goal of political re-unification.

Hu's new Taiwan policy could also be demonstrated in his handling of Beijing-Washington-Taipei relations. The new approach has been to restrain Taiwan's independence viaWashington diplomatically, rather than to constrain Taipei directly and militarily. This was in sharp contrast to the Jiang Zemin era, during which Beijing's sensitivity to Taiwan separatism led it to launch missile tests in the Taiwan Strait before the Taiwan presidential election in 1996. By contrast, Hu jintao looked to Washington to rein in behaviour by Taiwan that it considered destabilising.

For instance, during the 2004 presidential election campaign, Beijing unexpectedly did not resort to military intimidation or even verbal attacks.
Rather, as Chen stressed Taiwan independence and referendum issues on several occasions, Beijing encouraged Washington to admonish him while remaining silent itself. This change reflected the increased importance China has assigned to the US in its approach to constraining Taiwan. Beijing has changed its policy vis-à-vis Taipei from acting directly across the Strait to acting on Taipei indirectly through pressure exerted by Washington.

$\mathrm{Hu}$ Jintao's changed approach toward Taiwan could be observed in other areas as well. In the white paper China's National Defense in 2008 released on 20 January 2009, (25) more than six months after Taiwan President Ma Ying-jeou (馬英九) took office, Beijing stressed that the two sides of the Taiwan Strait have made progress in consultations under the common political framework of the "1992 Consensus." (26) China took a further step in its 2010 defence white paper, which proposed that Taipei and Beijing initiate talks about a "military security trust mechanism." (27)

Briefly, under Hu Jintao, China's approach to Taiwan has become decidedly more patient and less aggressive in response to Taiwan's de-emphasising of the independence issue. Beijing's attitude nowadays is softer, more proactive, and more flexible in engaging Taiwan economically, socially, and culturally. This has greatly reduced Taiwanese analysts' perceptions of threat from mainland China.

\section{Taiwan's military approaches toward the decreasing likelihood of conflict}

For the purpose of safeguarding Taiwan's military security from China's military threat, Taiwan's orientation of military strategy had long focused on a "defence-in-depth" strategy during the Lee Teng-hui era (1988-2000). The strategy was heavily influenced by the former ROC Chief of Staff, General Hau Pei-tsun's (郝柏村) operational concept of a "decisive military campaign at the water's edge" ( jue zhan tan tou 決戰 灘頭 ). (28) The concept mainly stemmed from Hau's assessment that it would be extremely difficult for the ROC armed forces to gain command of the air and sea over the Taiwan Strait, while mainland China could not conquer Taiwan without first landing on the island's beaches,

20. In stark contrast to the corresponding section in the 16th Party Congress speech in 2002.

21. Hu Jintao, "The 17th Party Congress Political Report," China Review News, 15 October 2007, www.chinareviewnews.com/doc/1004/6/8/8/100468847.html? coluid=88\&kindid=2592\&docid=100 468847 \& mdate $=1015101144$ (consulted on 13 December 2011).

22. "Chen cancels drill to match China," The China Post, 1 September 2004, www.chinapost.com.tw/taiwan/detail.asp?ID=52032\&GRP=B (consulted on 13 December 2011).

23. Wang Yu-Yan, "Hu Jintao said that the only task of the PLA is the war with Taiwan," Lianhe Bao, $27 \mathrm{Au}-$ gust 2007, p. A14.

24. The law was ratified at the 3rd Plenary Meeting of the 10th National People's Congress of the PRC, held on 14 March 2005, and went into effect immediately.

25. China's National Defense in 2008, Beijing, Information Office of the State Council, January 2009, www.china.org.cn/government/whitepaper/node_7060059.htm (consulted on 13 December 2011).

26. Ibid.

27. China's National Defense in 2010, Beijing, Information Office of the State Council, March 2011, http://news.xinhuanet.com/english2010/china/2011-03/31/c_13806851.htm (consulted on 13 December 2011). For an analysis of differences in confidence-building measures policy between Taiwan and China, see Arthur S. Ding, "Zhongguo de liang'an junshi huxin zhengce: jianchi yige zhongguo yuanze he zuizhong tongyi" (China's Military security trust mechanism: Upholding the one china principle and eventual re-unification), Yatai yanjiu luncong (Asia-Pacific Forum), no. 52, June 2011, pp. 86-106, www.rchss.sinica.edu.tw/capas/publication/newsletter/N52/52_01_03\%20WEB.pdf (consulted on 13 December 2011).

28. Hau Pei-tsun, Eight-Year Diary as the Chief of General Staff, Taipei, Commonwealth Publishing Co., 2000, vol. 1, p. 238. The tactical depth that Hau proposed encompasses a three-layered defence: (1) to check the enemy on his shore; (2) to strike the enemy in transit; and (3) to destroy the enemy on Taiwan's beachhead. 
and that by so doing it would suffer great casualties at the hands of Taiwan's ground forces. ${ }^{(29)}$

The assumption behind Gen. Hau's operational strategy was that given Taiwan's diplomatic isolation, it would not be appropriate for Taiwan to launch a pre-emptive strike, strategically or tactically, against Mainland China for fear of losing political support from allied and neighbouring countries. This implied that Taiwan could only take action after absorbing China's initial operational actions against it.

Further, despite the fact that Taiwan had a certain edge over China in terms of operational capabilities, Taiwan could not long sustain a war of attrition against China. As such, Taiwan had to preserve its ability to react after absorbing China's first strikes in the opening stage of the conflict. In order to do so, before China could launch any action against Taiwan, Taiwan's jet fighters and warships would have to be pulled back to the east of Taiwan so that they could be preserved. Operational action could then be executed after surviving China's opening attack. This explains why the Chiashan Air Force Base in Hualien and the Su'ao Naval Base were built following the late 1980s.

Gen. Hau's concept was further adopted in the 1996 National Defence Report (NDR), and the terms used to describe Taiwan's military strategy were fangwei gusou youxiao hezu (防衛固守, 有效嚇阻 solid defence, effective deterrence). (30) The concept was given official definition in the 1998 NDR. It was defined as "a kind of defensive deterrence" aimed at dissuading opponents from attacking by convincing them that the cost of using military force will outweigh the gains they might get from employing force of arms. ${ }^{311}$

Broadly speaking, the 1995/1996 Taiwan missile tests demonstrated that China's ballistic missiles could easily penetrate Taiwan's layered defences and cause significant damage to the island, potentially rendering counteroperations by Taiwan ineffective. The crisis exposed critical shortcomings in Taiwan's "defence-in-depth" strategy, and called into question the validity of continuing to rely on such an approach. The strategy was subsequently questioned by many civilians and Democratic Progressive Party (DPP) legislators, including future president Chen Shui-bian (陳水扁). ${ }^{(32)}$ In order to diffuse potential criticism over not being able to defend against a potential missile attack by China, Taiwan rushed to procure missile defence systems from the US and initiated several programs for developing indigenous cruise and ballistic missiles under the instruction of then-President Lee Teng-hui.

\section{The DPP's military strategy and operational doctrine}

The Chen Shui-bian administration amended Taiwan's traditional military strategy and operational doctrine during the period 2000-2008. The traditional military strategy was reversed from "solid defence, effective deterrence" (fangwei gushou, youxiao hezu) to "effective deterrence, solid defence" (youxiao hezu, fangwei gushou). ${ }^{(33)}$ Behind this inversion lay a new perception of the value of space in the Strait. In brief, whereas "solid defence" refers to traditional concepts of ground warfare, "effective deterrence" refers to air, naval, and information counter-measure capabilities. ${ }^{\left({ }^{34}\right)}$ This inversion was very significant in terms of defence resource allocation: it entailed a boost to the status of the navy, the air force, and units dedicated to information operations and information warfare while downgrading the role of the army.

Chen's administration also put forward a new operational doctrine of "fighting the decisive military campaign beyond the border" ( jue zhan jing wai 決戰境外 ) in line with the new military strategy. In declaring the new doctrine on 16 June 2000 during a speech at the National Military Academy, Chen said that Taiwan must develop military capabilities including "high precision strikes, early warning capability and intelligence superiority, basing itself on the objective of winning a decisive battle outside our territory." (35) The new doctrine tried to accomplish several goals, including seizing the initiative as quickly as possible in response to a Chinese attack; destroying Chinese forces at sea and in the air before they reach the beaches; and launching precision deep strikes at PLA command and control centres, logistics and support nodes, airbases, and other military targets on the mainland. (36)

Chen's new approach to the defence of Taiwan caused heated debate in Taiwan and China. For China, the new military strategy and operation doctrine were perceived as provocative, with many mainland analysts seeing it against the backdrop of President Bush's large arms sales package as evidence of a conspiracy between Taiwan and the Bush administration to upgrade security relations and prepare the way for Taiwan independence.

Debates in Taiwan centred on the implications of preparing for war-fighting efforts "beyond the borders," as well as the role and function of different services in the new strategy. Gen. Hau Pei-tsun was one of those who adamantly opposed the new approach to defending the ROC. One question was whether or not Taiwan had the capacity to launch a truly "decisive" military campaign, with Gen. Hau arguing that "decisive" campaigns could only be launched by stronger powers against weaker powers rather than the other way around. This line of analysis implied that Taiwan, as the weaker power, should pursue a strategy of protracted warfare with the aim of preserving as many capabilities as possible for the final campaign against the enemy's landing forces once they arrived on Taiwan's coastal beaches. ${ }^{(37)}$

Another debate involved how to assign the roles of the different military services in defending Taiwan. For Gen. Hau, the priority should be on air superiority and sea denial, but the goal is to preserve strength for strategically protracted warfare. If decisive campaign is launched by employing air and naval force at the outset of the campaign, Hau worried that Taiwan's defence capabilities would be totally exhausted at the opening stages of any cross-Strait conflict. ${ }^{(38)} \mathrm{A}$ final argument focused on whether or not the ROC armed forces could or should conduct a campaign beyond Taiwan's borders. Again, Gen. Hau adamantly opposed the idea of a campaign beyond the border, arguing that it implied a proactive and pre-emptive attack on the mainland, a mission beyond Taiwan military's capability.

29. Ibid.

30. ROC 1996 National Defense Report, NDR, Taipei, Ministry of National Defense, 1996, pp. 63.

31. NDR 1998, p. 53.

32. York W. Chen, "The Evolution of Taiwan's Military Strategy: Convergence and Dissonance," China Brief, vol. 9, Issue 23, 19 November 2009, pp. 8-9.

33. Chen, "The Evolution of Taiwan's Military Strategy," pp. 8-11.

34. Martin Edmonds and Michael Tsai, Defending Taiwan: The Future Vision of Taiwan's Defence Policy and Military Strategy, London, Routledge, 2003, pp. 6-7.

35. Chen Shui-bian, "Decisive battle outside the territory," a speech given at the Military Academy on 16 June 2000, reprinted in Taiwan Defense Affairs, no. 1, 1 October 2000, pp. 129-132.

36. Su Tzu-yun, "The Evolution of Taiwan's Defence Strategy and Defence Concept of Taiwan's New Administration," Taiwan Defense Affairs, no. 1, 1 October 2000, pp. 124-125.

37. This conception can explain why Gen. Hau proposed an operational doctrine of defence-in-depth, and built a large air force base and naval port in east of Taiwan region. Hau Pei-tsun, "Jing wai jue zhan'xing bu tong" (Fighting a decisive campaign beyond the border is not feasible), China Times, 5 July 2000, www.cetin.net.cn/cetin2/servlet/cetin/action/HtmlDocumentAction;jsessionid=BC53BCEAA818FD9 40EFB757B200069B7? baseid=1\&docno=149652 (consulted on 13 December 2011). 
Taiwan gradually reoriented its defence strategy following Chen's election in 2000, and two years later the National Defense Report 2002 emphasised the goal of building up Taiwan's counterstrike capabilities by transforming the ROC's traditional operational doctrine from "maintaining command of the air and sea, conducting anti-landing" to "maintaining command of the air and sea, conducting defensive ground operations, and maximising joint combat capabilities." (39) According to the National Defense Report 2004's comprehensive description of the "Active Defence" strategy, counterstrikes would include information operations, electronic warfare, long-range precision strikes, air and naval forces, and special operations. The objective of the counterstrikes would be to "rapidly paralyze the enemy's critical nodes and delay its invading operation tempo, so as to disrupt its ambition of winning a decisive victory in the first battle and swiftly ending the war." (40) Under the DPP's idea of active defence, the mass production of Hsiung Feng (HF)-2E land-attack cruise missiles became a vital aspect of Taiwan's military modernisation and strategic defence capabilities.

In addition, every military exercise and training event undertaken during the DPP era was designed to tackle scenarios focused on possible PLA action against Taiwan and countering the PLA's new capabilities. After the 1995-1996 crisis, the PLA started to focus on acquiring capabilities applicable to Taiwan scenarios, including improved Special Operations Forces, enhanced reconnaissance and surveillance units, and increased amphibious training. These units are being trained and equipped not only to conduct an amphibious invasion, but also to support naval and airborne strikes against Taiwan, including: (1) reconnaissance and targeting; (2) small-scale strike missions, such as decapitation efforts; (3) battle damage assessments; and (4) attacks on civilian infrastructure and military facilities.

In order to deal with the threat posed by Chinese missile attacks and/or decapitation operations, Taiwan improved its military exercises designed to assess training and readiness. Every year, Taiwan's premier annual military exercise, the Han Kuang exercise, is premised on the defence of Taiwan against various kinds of PLA attacks, including responding to threats to the island's air defences; anti-amphibious and anti-airborne assault operations; anti-submarine warfare; air-ground integration warfare; counter-terrorism; defence of civilian and urban infrastructure warfare; information warfare (IW) and counter-IW; reserve command integration; and Taiwan Air Force use of non-airfield sites. Additionally, smaller exercises have focused on counter-terrorism, reserve force mobilisation, and anti-decapitation drills.

In spite of these changes in defence posture, debate continues within Taiwan over the most appropriate military strategy and operational doctrine for the ROC. Can China be deterred from taking military action against Taiwan? Since it is completely unrealistic to pursue a true military balance in the Taiwan Strait, many ROC-based analysts argue for developing an asymmetric equilibrium, in which the US is the balancer and Taiwan depends on American investment and military support to deter China.

\section{Taiwan's Military Strategy and Operational Doctrine since 2008}

With regard to military strategy, the Ma Ying-jeou administration returned to the pre-Chen Shui-bian era defence strategy, emphasising "solid defence and effective deterrence." This reversion was written into the 2009 Quadrennial Defence Review (QDR) and 2009 National Defence Report (NDR). ${ }^{(41)}$ The interpretation is that when war is inevitable, the military should maximise joint operational capabilities, incorporate all-out defence capabilities, and engage in homeland defence, in order to reject, repel, and eliminate enemy forces and ensure national security. ${ }^{(42)}$

This strategy has also been referred to as a "Hard ROC" strategy. The 2009 QDR stipulates that Taiwan's defence planning is guided by a strategy of "Solid as Bedrock" ( gu ruo pan shi 固若磐石) approach to homeland defence focused on: (1) war prevention, (2) homeland defence, (3) contingency response, (4) conflict avoidance, and (5) regional stability. ${ }^{(43)}$ Though there is no operational doctrine derived from this strategy, it does imply that solid defence is the major means to accomplish effective deterrence, and that in the wake of the revolution in military affairs, a joint operation by all three services and social sectors has become necessary for executing solid defence. ${ }^{(44)}$

Under the Ma administration's approach to defending the ROC, air superiority and sea denial capabilities aim to delay, slow down, and repel China's military operation after absorbing the PLA's opening attack, and are intended to support a decisive military campaign on the beaches when the enemy is most vulnerable. Information and cyber operations are not ignored in employing this traditional doctrine, and play a role in weakening the PLA's ability to leverage information in support of war-fighting operations. (45) The concept of a "Hard ROC" strategy also emphasises increasing the fortification and emplaced defences of the island. (46)

Despite the fact that the Ma administration has decided on a defensively-oriented strategy, it has continued to focus on producing advanced ballistic and cruise missiles that can augment deterrence by threatening unacceptably painful retaliation against the mainland. For instance, both the 2009 QDR and the 2009 NDR suggest that Taiwan should keep strengthening and developing defensive counter-measures and asymmetric capabilities to fight against the enemy's centre of gravity. ${ }^{(47)}$ As a consequence, the budget for developing the HF-2E missile has been maintained since 2008. In fact, while the production of ballistic and cruise missiles under the Chen administration was seen by Beijing as provocative because they could be used to support the pursuit of Taiwan independence, they do not appear to elicit similar anxieties today because the Ma administration does not publicly challenge China's bottom-line one-China principle. ${ }^{(48)}$

If defence policy is an extension of politics, President Ma's military strategy is in line with his overall security policy. On May 13, 2011 when Ma

39. NDR 2002, p. 80.

40. NDR 2004, pp. 64-65

41. The official report was made based on amended National Defence Law, and the amendment was ratified by the Legislative Yuan in July 2008. The amendment requires any new president to present his/her defence strategy within ten months after taking office, and the 2009 Quadrennial Defence Review is the first one ever. For the report, see www.mnd.gov.tw/QDR/en_menu.htm (consulted on 13 December 2011).

42. Ibid., pp. 11-12. To achieve these aims, Taiwan's armed forces must effectively: (1) ensure the territorial integrity of the nation; (2) maintain a strong deterrent and sufficient war fighting capabilities; (3) secure sea and aerial lines of communication and be ready to carry out counter-blockade missions; (4) prevent enemies from approaching ROC territory through joint interdiction; and (5) to prevent enemy forces from landing on Taiwan's shores through ground interdiction at the water's edge.

43. QDR 2009, pp. 10-11.

44. Personal interview with retired Taiwan defence officials who were in charge of drafting the 2009 QDR, September 2011.

45. Personal interview, ibid.

46. Chen, "The Evolution of Taiwan's Military Strategy," p. 10.

47. QDR 2009, p. 42; p. 48; and NDR 2009, p. 80.

48. Reuters, "China military buildup is US-focused: Mullen," Taipei Times, 6 May 2009, www.taipeitimes.com/News/front/print/2009/05/06/2003442869 (consulted on 13 December 2011). 
held a teleconference with the Washington, DC-based Center for Strategic and International Studies (CSIS), he laid out his "Three Lines of Defence" ( san dao fan xian 三道防線) security policy for ensuring the peace and prosperity of Taiwan. ${ }^{(49)}$ According to $\mathrm{Ma}$, the three lines are: 1) to develop institutionalised mechanisms for dealing with China; ${ }^{(50)} 2$ ) to demonstrate to the global community Taiwan's national strength and soft power as a peacemaker and a provider of humanitarian aid; (51) and 3) to combine diplomacy and defence to win more international support. During his CSIS talk, Ma argued that although defence comes third in this sequence, it remains critical, citing Sun Tzu's argument that the best defence is to employ strategy, followed by diplomacy, with reliance on force as the worst option. ${ }^{(52)}$

A further observation is that Taiwan cannot afford to compete with China militarily due to Taiwan's small economic size. In this circumstance, Taiwan's best strategy is to focus its deterrent efforts as non-provocatively as possible on the Mainland's centre of gravity so that China can be deterred without being provoked, and Taiwan's economy can continue to develop while de facto political independence can be sustained.

\section{Taiwan's military modernisation and CBMs with China}

In spite of the fact that both sides of the Taiwan Strait are moving in a more pragmatic and mutually-beneficial direction, Beijing has never given up its military preparations against Taiwan. ${ }^{(53)}$ China has been rigorously developing state-of-the-art technologies and weapon systems, such as anti-satellite weapons, aircraft carriers, DF-16 and DF-21 ballistic missiles, ${ }^{(54)}$ the J-20 stealth fighter jet, ${ }^{(55)}$ advanced submarines, and large air and sea transport vehicles with the aim of establishing A2/AD capabilities. This was reconfirmed by comments by Chinese Defence Minister Liang Guanglie, who told a delegation from the Japan Self-Defence Force on 11 June 2010 that the "center of gravity for China's military development is Taiwan affairs." (56)

Cross-Strait relations may have stabilised in recent years, but Taiwan's security still depends very heavily on the continued support of the US. Following the 1995-96 Taiwan Strait crisis, Taiwan's military budgets between 1995 and 1999 averaged roughly US\$ 9 billion per year, which accounted for about 3.3 percent of GDP per year and 22.7 percent of annual government outlays. During the two terms of the Chen administration, Taiwan's annual defence budget decreased to just 2.5 percent of GDP per year, while averaging approximately US\$ 8.8 billion per year, or 17 percent of total annual government spending per year. Over the past three years of the $\mathrm{Ma}$ Ying-jeou administration, Taiwan's defence budget has consistently declined from US\$10.5 billion in 2008, to US\$9.6 billion in 2009, to US\$ 9.3 billion in 2010. The trend of Taiwan's shrinking military budget might limit Taiwan's ability to support military research and development, a potentially troubling development for Washington if it implies growing ROC reliance on the United States. ${ }^{(57)}$

With American support, in 2005 Chen announced the goal of reversing the declining spending trendlines and increasing the military budget to 3 percent of GDP by 2008. Washington encouraged Taiwan to boost its defence spending, and to concentrate on the challenges of hardening and sustaining forces. ${ }^{(58)}$ Since his election in 2008 , Ma promised to sustain military budgets at 3 percent of GDP, a commitment reaffirmed in QDR 2009 , though this has proven difficult. Despite the relatively small size of
Taiwan's military budget, it continues to seek to purchase weaponry from the US with the goal of building a smaller and leaner deterrent force in order to maintain peace in the Taiwan Strait.

Currently, Taiwan is seeking to transform the ROC armed forces into a smaller, more modernised and more professional force for homeland defence. ${ }^{(59)}$ With improved relations across the Taiwan Strait in recent years, Taiwan has set the goal of turning its military into an all-volunteer service by the end of 2014. With the goal of building an all-volunteer military, Taiwan looks forward to building a small but strong elite force that will offer a "Solid Defence and Effective Deterrence." Redefining its new direction, Taiwan cannot compete with China in the arms race. Winning is no longer a matter of "an all-out elimination of enemies" but rather of "defending every inch of the territory by expelling the enemies from landing," according to the 2009 NDR. ${ }^{(60)}$

At present, the ROC Army has approximately 200,000 personnel equipped with 1960s-era M-48H Brave Tiger tanks equipped with upgraded sensors and electronics; M-60A3 main battle tanks; and newer $\mathrm{M}$ 113 armoured personnel carriers. ${ }^{(61)}$ Much of the Army's tube artillery is towed, while it also deploys a variety of multiple rocket launchers, including the Ray Ting-2000, which is a domestic variant of the American M-270 Multiple Launch Rocket System. Its fleet of AH-1W Cobra attack helicopters is being supplemented with the AH-64D Apache equipped with the Longbow radar system, and it is expected to get UH-60 Blackhawk trans-

49. "President Ma Ying-jeou and CSIS Video conference," press released by Taipei Economic and Cultural Representative Office (TECRO) in the US, 14 May 2011, www.taiwanembassy.org/US/ct.asp?xltem= $198842 \& c t$ Node $=2300 \& \mathrm{mp}=12$ (consulted on 13 December 2011).

50. The latest public opinion survey by the MAC (Mainland Affairs Council) in June 2011 indicated that the majority of the public positively appraises institutionalised cross-Strait negotiations, with over 70 percent of the public supporting the handling of issues related to cross-Strait exchanges through institutionalised cross-Strait negotiations. Refer to ROC Mainland Affairs Council, "MAC: The majority of the public highly approve institutionalised cross-Strait negotiations," Press Release no. 041, 23 June 2011, www.mac.gov.tw/ct.asp?xltem=95883\&ctNode=6256\&mp=3 (consulted on 13 December 2011).

51. Ma's soft power includes respect for intellectual property rights, a comprehensive social infrastructure, and educated labour force.

52. Zhang Yong-tai, "Ma Ying-jeou quanshi Taiwan fangwei sandao fangxian" (President Ma interprets the three-line defence for Taiwan), www.voafanti.com/gate/big5/www.voanews.com/chinese/news/ 20110628-ma-three-lines-defense-124638694.html (consulted on 13 December 2011).

53. In fact, around 50 percent of the public in Taiwan still feel China's hostility towards the island, according to the MAC's survey in May 2011. On the security issue, the survey of the MAC in June 2011 also indicated that about 88.4 percent of the public still advocate maintaining the status quo on the Taiwan Strait, while the possibility of a PLA threat is decreasing. Refer to MAC, "Survey of 'the public views about recent cross-Strait relations'," 27-30 May 2011, www.mac.gov.tw/public/Attachment/ 1671684874.pdf (consulted on 13 December 2011); "MAC: The majority of the public highly approve institutionalised cross-Strait negotiations," Press Release no. 041, 23 June 2011, www.mac.gov.tw/ct.asp? xttem $=95883 \&$ ctNode $=6256 \& \mathrm{mp}=3$ (consulted on 13 December 2011).

54. Rich Chang, "China aims new missile types at Taiwan, NSB says," Taipei Times, 17 March 2011, www.taipeitimes.com/News/front/archives/2011/03/17/2003498376 (consulted on 13 December 2011).

55. Carlo Kopp, "The Strategic Impact of China's J-20 Stealth Fighter," Air Power Australia - Australia's Independent Defence Think Tank, 9 January 2011, www.ausairpower.net/APA-NOTAM-090111-1.html (consulted on 13 December 2011).

56. "China Seeks to Neutralize Japan-U.S. Security Treaty," The Asahi Shimbun, 21 June 2010, www.asahi.com/english/TKY201006200174.html (consulted on 13 December 2011). Also see Yang Nien-dzu, "Taiwan's Defense and Strategy," India Strategic, January 2011, www.indiastrategic.in/topstories867.htm (consulted on 13 December 2011).

57. "Cross-Strait Military Imbalance 'Troubling': US," The China Post, 18 August 2010, www.chinapost.com.tw/taiwan/national/national-news/2010/08/18/269066/Cross-straitmilitary.htm (consulted on 13 December 2011).

58. Shirley A. Kan, "Taiwan: Major U.S. Arms Sales since 1990," CRS Report for Congress, 28 September 2010, p. 31.

59. NDR 2009, p. 113

60. Ibid.

61. The Military Balance 2011, London, International Institute for Strategic Studies, 2011, pp. 272-273.

62. Kan, "Taiwan: Major U.S. Arms Sales since 1990," p. 65. 
port helicopters in the near future. ${ }^{(62)}$ The ROC Air Force has about 45,000 personnel and fields 450 fighter-bombers, ranging from obsolescent F-5 fighters to the Ching-kuo Indigenous Defence Fighter (IDF), and about 200 F-16A/B and Mirage 2000 fighters combined. ${ }^{(63)}$ The proposed sale of 66 F-16 C/D fighters would replace and allow the phasing out of the aging F5 fighters. ${ }^{(64)}$ The ROC Navy (ROCN) has 45,000 personnel and is mostly equipped with retired US naval vessels, including four Kidd-class destroyers armed with Harpoon anti-ship missiles and SM-2 medium-range surfaceto-air missiles. The ROCN has 22 frigates, which will be supplemented with eight Perry-class frigates armed with a mix of anti-submarine and antiship weapons systems and more than 69 fast-attack craft equipped with anti-ship missiles. ${ }^{65)}$

Missiles are high priority items in Taiwan's military development. These include anti-ship cruise missiles, such as HF-2E missiles, and missile defence system such as PAC-3 Patriot and Tien Kung surface-to-air missile systems manned by the Army. Besides, Taiwan is expected to mass produce a powerful Wan Chien air-to-surface missile system designed to nip a Chinese invasion in the bud by striking airfields and harbours on the mainland. (66) Notably, Taiwan presented the indigenous HF-III missiles on the same day that China began sea trials of its first aircraft carrier, by describing the missile as a "carrier killer" which has been deployed on Taiwan's Perry-class frigates. ${ }^{(67)}$

\section{New security perceptions and changed military role since May 2008}

Paradoxically, notwithstanding China's continued military build-up over the past several years, Taiwan's perception is that the likelihood of military conflict with China is quite low, both now and for the foreseeable future. ${ }^{(68)}$ This perception has prevailed since the election of Ma Ying-jeou, and can be attributed to several factors, including perceptions of China's near-term intentions and an improved understanding of China's red-lines derived from China's new Taiwan policy, its leaders' growing realisation of Taiwan's complicated domestic politics, and the US's determination to continue to play an important role in the Asia-Pacific region.

Along with the perceived declining likelihood of military conflict in the Taiwan Strait, hopes over the possibility of using confidence-building measures and ending hostility in the Taiwan Strait have grown over the past few years. The purpose of employing such measures would be to develop stable and predictable patterns of behaviour that both sides could use to gauge intentions, avoid accidental conflict, and maintain the peace. Furthermore, some Taiwan observers have raised the idea of developing cooperation with the mainland in the field of non-traditional security, including combating transnational crime, terrorism, drug trafficking, pandemic disease, disaster relief, and humanitarian rescue. These areas are less politically sensitive and could provide experience working collaboratively before moving on to more challenging bilateral defence issues.

The Typhoon Morakot disaster of 8 August 2009 was a turning point for the development of Taiwan's military. Since the disaster, Taiwan's armed forces have been charged with preparing not only for traditional threats from China, but also for dealing with non-traditional security missions such as disaster relief and counter-terrorism. ${ }^{(69)}$ The political consequences of the Ma administration's perceived mishandling of the relief operations led directly to a rise in pressure on the defence establishment to develop the ability to respond to natural disasters, which may entail some trade- offs between preparations for traditional combat operations and preparations for disaster relief. Even though the Taiwan government insists that enhancing combat operations and maintaining deterrent capabilities remain the military's first priorities, readiness for disaster relief is clearly emerging as a core mission for Taiwan's armed forces as well, with some commentators arguing that natural disasters pose a greater threat than the military of the PLA. ${ }^{(70)}$

In addition to focusing on defensive-oriented strategies and non-traditional missions such as disaster relief, the Ma administration has also begun to explore possible confidence-building measures (CBMs) across the Taiwan Strait. To date, most of the CBM experiences of Taipei and Beijing have consisted of unilateral steps involving unilateral declarations and responses of limited reciprocity. For example, Ma's decision to de-emphasise independence issues and his pledge of "Three No's" can be considered declaratory confidence-building measures, as can his declaration in his inaugural speech that he was prepared to negotiate with Beijing based on the "1992 consensus."

For China's part, its 2010 defence white paper not only stressed the importance of the "1992 consensus" in cross-Strait relations, but also pointed out that "the two sides may discuss political relations in the special situation that China is not yet reunified in a pragmatic manner. The two sides can hold contacts and exchanges on military issues at an appropriate time and talk about a military security mechanism of mutual trust, in a bid to act together to adopt measures to further stabilise cross-Strait relations and ease concerns regarding military security." (71) This was the first time that Beijing publicly stated that two sides of the Strait could explore the establishment of military security trust under the one-China principle.

\section{Conclusion}

Since the late 1980s, Taiwanese perceptions of military threat from China have risen and fallen, and these shifting perceptions have to a significant extent reflected changes in China's overall cross-Strait policy. Prior to 1993, when Chinese policy emphasised peaceful re-unification under the "one country, two systems" approach and the two sides were engaged in bilateral discussions, perceptions in Taiwan of a military threat from China were muted. After 1993, when China launched a series of military exercises aimed at preventing the Lee Teng-hui and Chen Shui-bian administrations

63. The Military Balance 2011, op. cit., p. 274.

64. Dean Cheng, "Meeting Taiwan's self-defense needs," Backgrounder, no. 2379, The Heritage Foundation, 26 February 2010, pp. 6-7.

65. The Military Balance 2011, op. cit., p. 273.

66. Agence France-Presse, "Taiwan developing new air-to-surface missile: Lawmaker," Defense News, 6 September 2011, www.defensenews.com/story.php?i=7600533\&c=air; land\&s=TOP (consulted on 13 December 2011).

67. Agence France-Presse, "Taiwan Hails Missile as 'Aircraft Carrier Killer'," Defense News, 6 September 2011, www.defensenews.com/story.php?i=7600533\&c=ASI\&s=LAN (consulted on 13 December 2011).

68. Refer to the "Cross-Strait Peace Indices" (CSPI) of the Exchange for Future Events, the largest Chineselanguage virtual markets based in Taipei. The CSPI shows that the aggregate peace index remains unchanged and the expectations of military conflict remain low, www.xfuture.org/contract_groups/2378 (consulted on 16 December 2011).

69. Chih Judy Lin, "Typhoon Morakot and impact on Taiwan," MCSS/Center for Security Studies in Taiwan, 3 September 2009, www.mcsstw.org/www/research2.php?article_id=67\&keyword=mcss_briefing (consulted on 13 December 2011).

70. Michael S. Chase, "The role of U.S. arms sales in Taiwan's defense transformation," China Brief, vol. 10, no. 5, 5 March 2010, pp. 5-7.

71. China's National Defence in 2010, Beijing: Information Office of the State Council, March 2011. 
from pursuing "Taiwan independence," perceptions of a military threat from China heightened. After Hu Jintao took power in 2002 and adopted a more moderate policy toward Taiwan, perceptions of a Chinese military threat once again declined. This perception has held up in spite of the fact that the Chinese military is undertaking a comprehensive military modernisation effort and has placed more than a thousand missiles across from Taiwan.

Taiwan's force posture and procurement policies have evolved in response to Taiwan's perceptions of the threat posed by China. The switch in military strategy and operational doctrine from "solid defence and effective deterrence" and "defence in depth" to "effective deterrence and solid defence" and "decisive campaign beyond territory" during the Chen Shuibian era was an example of how Taiwan's defence strategy has evolved in light of the challenges posed by China's military power.

It is worth reiterating that the more moderate policy line toward Taiwan taken by China under the Hu administration does not in any way imply a shift in the PRC's ultimate policy of achieving reunification with Taiwan. The adoption of a more moderate policy line by Beijing was made in response to the backlash against the mainland's more hawkish behaviour during the 1995-96 Taiwan Strait crisis and to comport with China's strategy of emphasising its peaceful rise and peaceful development.

Irrespective of the reasons for its adoption, Hu's more moderate Taiwan policy line has certainly had a deep impact on Taiwan's security perceptions, as many observers' perceptions of a military threat from China have declined despite the mainland's continued military modernisation and growing deployment of missiles opposite Taiwan. Reflecting these muted security concerns vis-à-vis the mainland, one recent poll showed that only 10.1 percent of Taiwanese surveyed were worried about the possibility of military conflict in the Taiwan Strait in the near future. ${ }^{72)}$

How long such perceptions of a relatively benign cross-Strait security environment can persist while fundamental political differences remain between Taiwan and China is an open question. One element that may complicate efforts to maintain the cross-Strait status quo stems from shifts in public identity in Taiwan. Despite the growing closeness in economic ties between Taiwan and China under President Ma Ying-jeou after he took office in May 2008, the percentage of respondents identifying themselves in opinion surveys as "Taiwanese" has continued to climb, from 48.4 percent in 2008 to 54.2 percent in 2011; during the same period, the proportion of respondents who identified themselves as "Chinese" fell to around 4 percent. ${ }^{(73)}$ Furthermore, widespread polling data shows that the number of those advocating the status quo (both a permanent status quo and temporary status quo) ${ }^{(74)}$ continues to grow, from 57.3 percent in 2008 to 60.1 percent in June 2011. ${ }^{(75)}$ These figures imply that China's moderate policy probably has not achieved everything that its authors have hoped.

What implication can be drawn from the analysis above? It is probably safe to say that although relations between Taiwan and China have improved under President Ma Ying-jeou, as long as fundamental political differences remain between Taiwan and China, and the mainland does not renounce the use of force, the possibility of armed conflict will remain, and Taiwanese perceptions of a military threat from China will not disappear completely.

72. Cross-Strait Peace Index (CSPI), http://xfuture.org/contract_groups/3a9c29ba-eb01-4f65-ac08fa4af41a5a0f (consulted on 13 December 2011)

73. "Identification Distribution in Taiwan, 1992-June 2011," Election Study Center (ESC), National Chengchi University (NCCU), http://esc.nccu.edu.tw/modules/tinyd2/content/TaiwanChineselD.htm (consulted on 13 December 2011)

74. The term "permanent status quo" implies a long-lasting situation of permanent peaceful separation in the Taiwan Strait; and the term "temporary status quo" implies a short-term separation in the Strait with the possibility of either re-unification or independence in the foreseeable future. Refer to "Re-unification vs. Independence Distribution in Taiwan 1994-June 2011," ESC, NCCU, http://esc.nccu.edu.tw/ english/modules/tinyd2/content/tondulD.htm (consulted on 13 December 2011). 